\title{
Biome variation, not distance between populations, explains morphological variability in the orchid bee Eulaema nigrita (Hymenoptera, Apidae, Euglossini)
}

\author{
Claudinéia Pereira Costa ${ }^{1,2}$, Clycie Aparecida Silva MaCHADO ${ }^{3}$, \\ Wellyngton Matheus Souza Santiago ${ }^{4}$, Rodrigo Pires DallacQua ${ }^{4}$, \\ Carlos Alberto GARÓFALO ${ }^{3}$, Tiago Mauricio FrancoY ${ }^{5}$

\footnotetext{
${ }^{1}$ Departamento de Genética, Faculdade de Medicina de Ribeirão Preto, Universidade de São Paulo, Ribeirão Preto, São Paulo, Brazil

${ }^{2}$ Department of Entomology, University of California, Riverside, CA, USA

${ }^{3}$ Departamento de Biologia, Faculdade de Filosofia, Ciências e Letras de Ribeirão Preto, Universidade de São Paulo, Ribeirão Preto, São Paulo, Brazil

${ }^{4}$ Instituto de Biociências, Universidade Federal de Mato Grosso do Sul, Campo Grande, Mato Grosso do Sul, Brazil

${ }^{5}$ Escola de Artes, Ciências e Humanidades, Universidade de São Paulo, São Paulo, São Paulo, Brazil
}

Received 25 September 2019 - Revised 29 April 2020 - Accepted 28 May 2020

\begin{abstract}
The sampling of orchid bees across different biomes provides an excellent opportunity to analyze morphological variability in this group. We examined the morphological variation of populations of Eulaema nigrita in the context of the determination of geographic origin. It also evaluated population variability of this group in different landscapes from two important biomes, Atlantic Forest, Brazilian Savanna, and the transition zone between them. These analyses were achieved by documenting the pattern of morphological differentiation using geometric morphometric analysis of the wings of 256 individuals, sampled from nine locations, from four different physiognomies. Results indicated that individuals from the Atlantic Forest physiognomies are larger than the ones from the Savanna. The clusterization of individuals was based on landscape features of the sampling areas. The results indicate little or even a complete absence of population structure. Overall, site-specific population differentiation is not strongly supported by wing traits, reinforcing the statement consistent with the broader pattern that orchid bees have a high migratory capacity. However, the subtle differentiation may indicate the existence of locally adapted traits kept by female philopatry or phenotypic plasticity triggered by environmental factors yet to be studied.
\end{abstract}

\section{Euglossini / geometric morphometrics / Brazilian Savanna / Atlantic Forest}

\section{INTRODUCTION}

Bees are the most frequent flower visitors in forests (Neff and Simpson 1993) and provide

Electronic supplementary material The online version of this article (https://doi.org/10.1007/s13592-020-00776-z) contains supplementary material, which is available to authorized users.

Corresponding author: T. Francoy, tfrancoy@usp.brM. Francoy, tfrancoy@usp.br

Responsible editor: Marina Meixner crucial pollination services in a wide number of agricultural and natural ecosystems (Klein et al. 2007; Brown and Paxton 2009; Willmer 2011). In the Neotropical region, the Euglossini tribe, commonly known as orchid bees, stands out as particularly important pollinators (Tonhasca et al. 2003). Studies have shown that both male and female orchid bees pollinate a wide number of plant species while foraging for nectar, pollen, and resins (see Ramirez Arriaga and Martinez Hernandez 1998; Ramírez et al. 2002; Ospina- 
Torres et al. 2015; Ramírez 2019). Specifically, $10 \%$ of Neotropical Orchidaceae, around 700 orchid species, is pollinated by male euglossine bees (Ramírez et al. 2002). Euglossine bees are abundant in low- or mid-elevation forests, comprising up to $25 \%$ of species in bee communities (Roubik and Hanson 2004). Many euglossine species have a strong association with forested areas and show the highest community richness in areas where precipitation exceeds $2000 \mathrm{~mm} /$ year (Dressler 1982).

Euglossine bees have recently attracted interest from the academic field, especially in the last two decades, with an increasing number of studies designed to catalog and recognize the diversity of this group throughout the Atlantic Forest (e.g., Rebêlo and Garófalo 1997; Sofia et al. 2004; Ramalho et al. 2009; Nemésio 2009; Rocha-Filho and Garófalo 2013, 2014; Giangarelli et al. 2015; Costa and Francoy 2017; Machado et al. 2018), with additional studies on the population dynamics and genetic diversity of some species (e.g., Cerântola et al. 2011; Freiria et al. 2012; Rocha-Filho et al. 2013; Boff et al. 2014; Penha et al. 2015; Grassi-Sella et al. 2018). Among the approximately 206 known species of orchid bees, one of the most studied is Eulaema nigrita Lepeletier, which has a relatively broad geographical distribution (Moure 1950) and tends to inhabit open areas (Peruquetti et al. 1999). This species presents excellent flight and dispersal abilities (Ackerman 1983; Raw 1989) and is an extremely generalist species, with respect to floral diet (Dressler 1982; Ramalho et al. 2009; Silva et al. 2012). El. nigrita is relatively abundant in several ecosystems (Rebêlo et al. 2003), among them the Atlantic Forest (e.g., Aguiar and Gaglianone 2012; Cordeiro et al. 2013; RochaFilho and Garófalo 2014; Machado et al. 2018) and Brazilian Savannas (e.g., Ramalho et al. 2009; Faria and Silveira 2011; Silveira et al. 2015). Due to its occurrence as a dominant species in open and urban areas, it is considered to be an indicator species of disturbed areas (Morato et al. 1992; Peruquetti et al. 1999; Nemésio and Silveira 2007).

In the last 20 years, geometric morphometrics of wings has become an important tool for the identification and evaluation of insect diversity, especially in bees (e.g., Francisco et al. 2008; Francoy et al. 2011; Francoy et al. 2016). This method describes shape by using the Cartesian coordinates of landmarks plotted on an image of a morphological structure and allows the researcher to reconstruct the shape of the studied structure. Because this approach employs a comprehensive statistical analysis to extract spatial information from morphological structures, it is more quantitative and accurate than traditional morphometrics (Bookstein 1998; Mitteroecker and Gunz 2009; Francoy et al. 2008, 2012). Geometric morphometric analysis of wings has proved to be a practical methodology for the discrimination of cryptic species (Francisco et al. 2008; Hurtado-Burillo et al. 2016) and geographic ecotypes (Francoy et al. 2011; Bonatti et al. 2014; Grassi-Sella et al. 2018) and for the identification of species (Francoy et al. 2009, 2012) and subspecies (Oleksa and Tofilski 2014; Silva et al. 2015). Its efficacy as a sensitive tool for differentiating among groups in these ways stems from wing shape being relatively conserved among individuals of the same species (Debat et al. 2003; De Souza et al. 2015). In this study, we used morphometric tools to investigate the population structure of El. nigrita sampled from nine different locations in the Atlantic Forest and Brazilian Savannas, in order to investigate species morphological responses to changes along with the tropical landscapes.

\section{MATERIAL AND METHODS}

\subsection{Sampling}

We used male individuals of El . nigrita, which were collected in Atlantic Forest remnants and Brazilian Savannas in the states of São Paulo (SP) and Mato Grosso do Sul (MS) (Table S1 and S2, Supporting information; Figure 1). Within the Atlantic Forest, we chose to consider different physiognomies. For Atlantic Rain forest, we collected bees in Parque Estadual Turístico do Alto

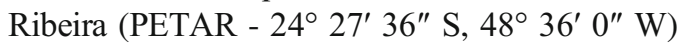
and in Ubatuba (UB - $22^{\circ} 27^{\prime} 0^{\prime \prime} \mathrm{S}, 52^{\circ} 10^{\prime} 0^{\prime \prime} \mathrm{W}$ ). For Atlantic semi-deciduous forest, samples were collected in Estação Ecológica de Paulo de Faria $\left(\mathrm{PF}-19^{\circ} 57^{\prime} 35^{\prime \prime} \mathrm{S}, 49^{\circ} 31^{\prime} 46^{\prime \prime} \mathrm{W}\right)$, 


\section{Mato Grosso do Sul State}

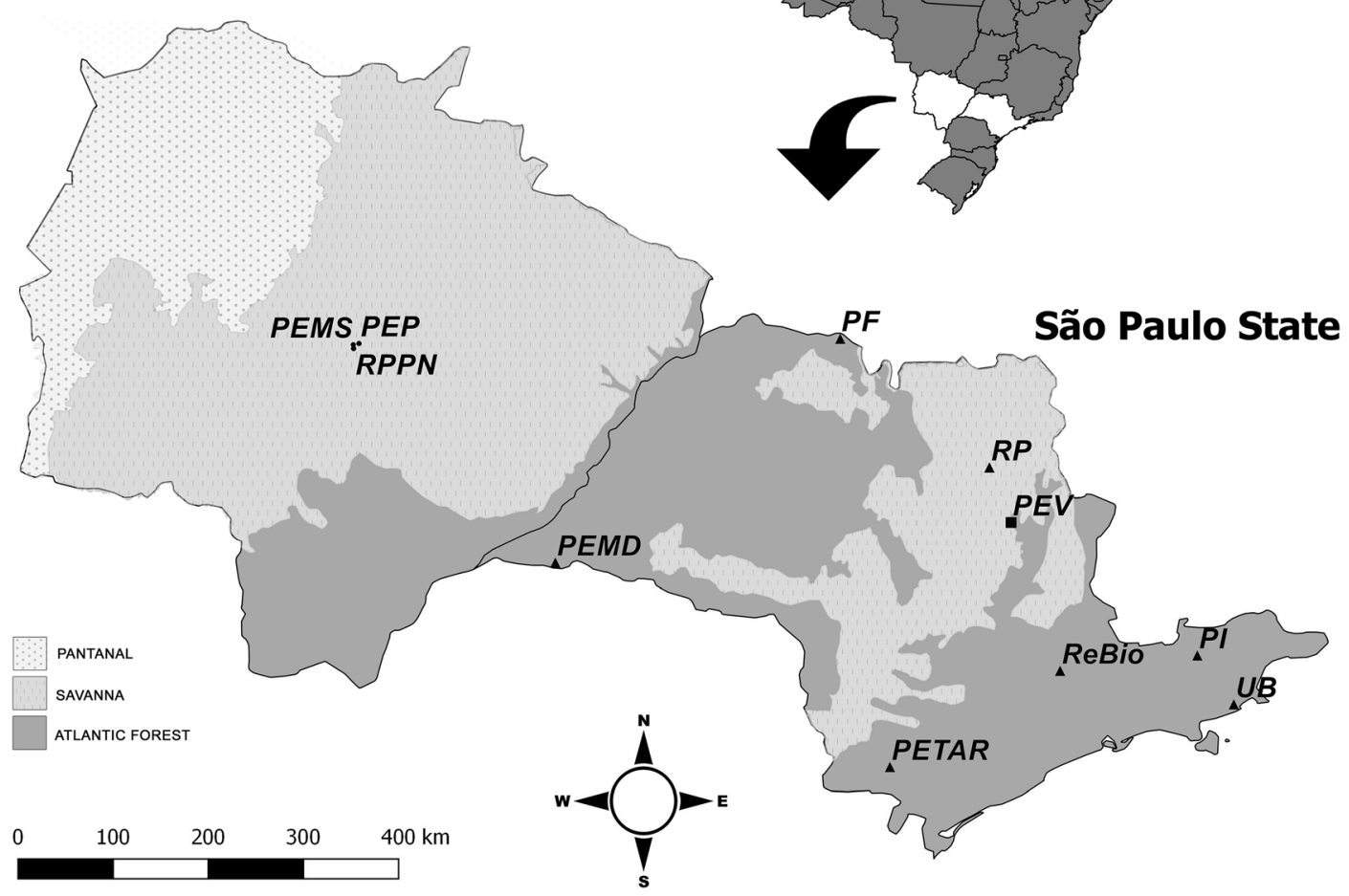

Figure 1. Sampling locations of the Eulaema nigrita in Atlantic Forest remnants and Brazilian Savannas in the states of São Paulo (SP) and Mato Grosso do Sul (MS). Estação Ecológica de Paulo de Faria (PF); Reserva Biológica da Serra do Japi (ReBio); Parque Estadual de Vassununga (PEV); Ubatuba (UB); Pindamonhangaba (PI); Parque Estadual Morro do Diabo (PEMD); Parque Estadual Turístico do Alto Ribeira (PETAR); Ribeirão Preto (RP); Campo Grande (CG). Black dots - samples collected in biome Atlantic Forest; black triangles — samples collected in biome Brazilian Savannas; black squares - samples collected in transition area Atlantic Forest and Brazilian Savanna in Parque Estadual de Vassununga (PEV).

Pindamonhangaba (PI - $22^{\circ} 55^{\prime} 50^{\prime \prime} \mathrm{S}, 45^{\circ} 27^{\prime} 22^{\prime \prime}$ W), Parque Estadual Morro do Diabo (PEMD $\left.22^{\circ} 27^{\prime} 0^{\prime \prime} \mathrm{S}, 52^{\circ} 10^{\prime} 0^{\prime \prime} \mathrm{W}\right)$, Reserva Biológica da Serra do Japi (ReBio - 23 13' 51" S, 46 56' 06" W), Ribeirão Preto (RP): Mata de Santa Tereza ( $21^{\circ} 12^{\prime} 54^{\prime \prime} \mathrm{S}, 47^{\circ} 50^{\prime} 36^{\prime \prime} \mathrm{W}$ ), and Campus USP $\left(21^{\circ} 09^{\prime} 31^{\prime \prime} \mathrm{S}, 47^{\circ} 51^{\prime} 55^{\prime \prime} \mathrm{W}\right)$. Parque Estadual de Vassununga (PEV - 21 $1^{\circ} 43^{\prime} 30^{\prime \prime} \mathrm{S}, 47^{\circ} 34^{\prime} 60^{\prime \prime}$ $\mathrm{W})$ is placed in a transition area between the Atlantic Forest and Brazilian Savannas. We also sampled bees in three urban forest remnants in Brazilian Savannas in Campo Grande (CG) - MS: Parque Estadual do Prosa (PEP - 20 27' 09" S, $\left.54^{\circ} 33^{\prime} 38^{\prime \prime} \mathrm{W}\right)$, Parque Estadual Matas do

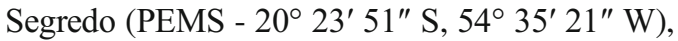
and Reserva Permanente do Patrimônio Natural da UFMS (RPPN - 2030' 30" S, 54 36' 58" W).

Bees were collected from December 1997 to November 1998 and from January to December 1999 in PF; from April 2011 to February 2013 in ReBio and PEV; April 2014 to March 2015 in UB and PI; May 2014 to April 2015 in PEMD and PETAR; during July 2014 in RP - Mata de Santa Tereza and during August 2017 in RP - Campus USP. In Campo Grande (CG) - MS, males were sampled during November 2016 in PEP and PEMS and during March 2017 in RPPN. The sampling method was based on Rebêlo and 
Garófalo (1991), with minor modifications. In brief, we used baits with scents prepared from cotton wool wrapped in gauze and tied with a string; they were fixed to tree branches at a height of $1.5 \mathrm{~m}$ above the ground and at a distance of 5$10 \mathrm{~m}$ apart. Bees were collected with entomological nets on sunny days from 8:00 to 15:00 h. For more details concerning the sampling methods, see Costa and Francoy (2017).

\subsection{Morphometric analyses}

Geometric morphometrics To analyze patterns of wing venation, the right forewings of $256 \mathrm{El}$. nigrita males were mounted between a microscope slide and coverslip and photographed with a digital camera connected to a stereomicroscope. A tps file was built from the images using the software tpsUtil version 1.70 (Rohlf 2015) to prepare a dataset of the Cartesian coordinates of the plotted landmarks. Eighteen landmarks (Figure 2) were plotted on each wing using tpsDig2 version 2.26 (Rohlf 2015). Landmarks were chosen according to previous studies on males of Euglossini (Francoy et al. 2012; Quezada-Euán et al. 2015).

Data analysis Geometric morphometric analyses were conducted using the software MorphoJ version 1.06d (Klingenberg 2011), whereby they were Procrustes aligned to identify the points of shape variation. We first produced a Procrustes fit to eliminate variation caused by differences in size, position, and orientation of the wings, and the residuals of this regression were used as "size free" variables. These data were used as input in a principal component analysis (PCA), canonical variant analysis (CVA), and discriminant function analysis (DFA). Bees were grouped according to their biomes and physiognomies. A leave-one-out cross-validation test was performed to assess the accuracy of the data. We also calculated the Mahalanobis square distances between the centroids of the groups' distribution and used it to construct a dendrogram of morphological proximity based on the neighbor-joining algorithm using MEGA 7.0 (Kumar et al. 2016). We ran a Mantel test using statistical package $\mathrm{R}$ version 3.3.3 (R Development Core Team 2017) on the
Mahalanobis square distances between the centroids of the groups and the geographic distances among the sampling locations (measured by Google Earth 7.3.0.3832/2017). We also employed the Mantel test on the Procrustes distances and the geographic distances between sites. We also used the wing centroid size as a proxy for body size (Zelditch et al. 2004; Outomuro and Johansson 2011) to assess whether bees from different populations differed in size (Rattanawannee et al. 2017). The centroid size was compared among biomes and physiognomies. This data was first tested for its normality and, as the distribution did not fit a normal distribution, they were compared using ANOVA on Ranks, on software Sigmastat version 3.5. The pair-to-pair comparison was made using Dunn's test, with $\alpha=0.05$

\section{RESULTS}

Statistical differences were found in the mean shape of the wing of El. nigrita among the biomes (Table I) and also among physiognomies (Table S3, Supporting information). The first 18 factors of these measures explained $90.98 \%$ of the total data variability, with the first two PCs explaining $29.54 \%$ of the total data variability (PC1 explained $16.17 \%$ and PC2 explained $13.38 \%$; Figure S1, Supporting information). The two first canonical variate functions were significant for the discrimination of bees from different areas $(p<0.0001$; Figure 3$)$. The scatterplot (Figure 3) shows a subtle separation among areas, although some overlapping can be observed. Based on the first CVA axes (Figure 3), we found two groups, one placed in the left-hand quadrant, Atlantic Forest, and another group in the right-hand quadrant with Brazilian Savannas. Bees from the transition area overlap with individuals from the other two areas. This result is confirmed when bees were grouped according to their physiognomies (Figure 4), in which two groups were found, where one group is placed in the left-hand quadrant, semi-deciduous Forest and rain Forest (physiognomies from Atlantic Forest), and the other group in the right-hand quadrant with Brazilian Savannas; the transition area overlaps with other areas. The discriminant analysis 


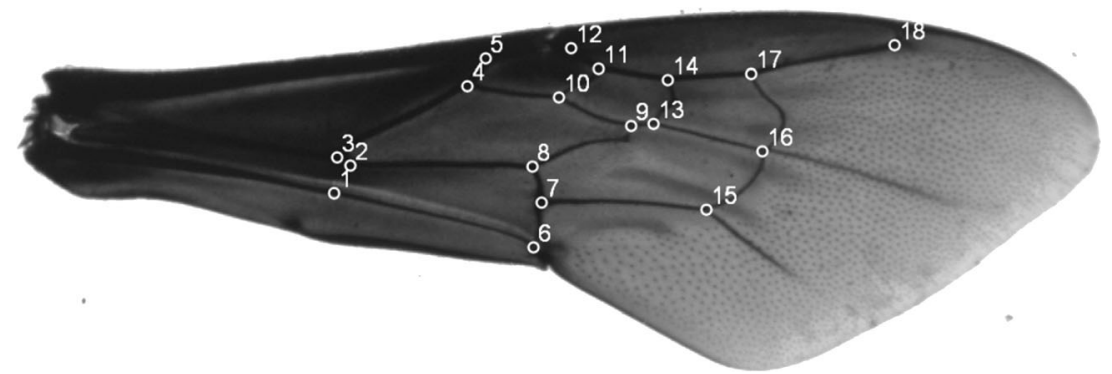

Figure 2. Forewing of Eulaema nigrita males, with 18 landmarks used in the geometric morphometric analysis.

showed $91.37 \%$ and $89.18 \%$ accuracy, for biomes (Table S4, Supporting information) and physiognomies (Table S5, Supporting information) respectively. Assignment of the specimens to geographical areas correctly classified approximately $68 \%$ of the total analyzed bees, which were grouped according to their biomes and physiognomies (cross-validation test showed $68.91 \%$ and $67.67 \%$ accuracy, for biomes and physiognomies respectively) (Tables S4, S5, Supporting information).

The two dendrograms of morphological proximity presented a similar topology (Figure 5), indicating similar relationships among populations. Figure 5a shows the transition area close to Atlantic Forest and Savanna in the external branch. A similar topology appeared when we analyzed morphological proximity about physiognomies (Figure 5b), rainforest, and semi-deciduous forest are placed together in one branch, close to the transition area, and Savanna remained outside the other physiognomies. The Mantel test correlating the geographic distances between fragments and the Mahalanobis squared distance and Procrustes distance between groups presented nonsignificant results $(r=0.368, p$ values $=0.067$ and $r=0.379, p$ values $=0.078$, respectively) .

The analysis based on the centroid size indicated that there were statistically significant differences among bees from different physiognomies $(p=0.000084)$ and among biomes $(p=0.00041)$. Bees from Brazilian Savanna were smaller than the ones from the transition area and also from the other physiognomies and biomes (Figure 6a, b, respectively). No statistically significant differences were found among the other groups in both analyses, biomes, and physiognomies.

\section{DISCUSSION}

Area and distance among different landscapes are the main factors used to explain species

Table I. Mahalanobis squared distances (below diagonal) and Procrustes distances (above diagonal) between mean wing shapes of the Eulaema nigrita from different Brazilian biomes. Respective $p$ values, given in brackets, were obtained from permutation tests (10,000 permutation runs). *Transition area Atlantic Forest and Brazilian Savanna in Parque Estadual de Vassununga (PEV)

\begin{tabular}{llll}
\hline & Transition area* & Savannas & Atlantic Forest \\
\hline Transition area* & & 0.012 & 0.009 \\
& & $(0.0002)$ & $(0.0014)$ \\
Savannas & 2.439 & & 0.013 \\
& $(<0.0001)$ & & $(<0.0001)$ \\
Atlantic Forest & 1.649 & 2.352 & \\
& $(0.0234)$ & $(<0.0001)$ & \\
\hline
\end{tabular}


diversity (McCoy and Mushinsky 1994) and population dynamics (Alder 1994; Aldaz 1994). Among the tools used to evaluate population dynamics, geometric morphometrics is especially promising in studies of insects due to its efficiency and low cost to benefit ratio. In orchid bees and other bees, geometric morphometric analysis of landmark Cartesian coordinates is a useful approach in studies of macro- and micro-evolution, being able to distinguish both species and populations. For example, geometric morphometrics of wings was used to identify species of Euglossa genus (Francoy et al. 2012). It was similarly employed to evaluate population structuring associated with landscape and habitat isolation of two species in Atlantic Forest, Euglossa annectans and Euglossa truncata (Grassi-Sella et al. 2018). The geometry of wing shape is less subject to environmental influence and more informative, in evolutionary terms (Dujardin 2008; Jirakanjanakit et al. 2008) than analysis of wing size (traditional morphometrics). Although there is a genetic basis to size variation, it can be labile and influenced by environmental features, e.g., temperature (Gibert et al. 2004; Polak et al. 2004) or relative humidity (Morales-Vargas et al. 2010) or food availability and/or quality (Quezada-Euán et al. 2011). Since there is a relation between wing size and body size in bees (Bullock 1999), our centroid size analysis indicated a variation in the size of individuals from different physiognomies and biomes. It is known that the pollen offer throughout the year can influence the body size of El. nigrita individuals (Peruquetti 2003). Brazilian Savanna biome presents a seasonal variation in plant activities, with an increasing pollen availability during the wet season (Batalha and Martins 2004; Leite et al. 2006). It may reflect directly on the smaller final mean size of males throughout the year. The same observation was made when comparing humandisturbed environments to undisturbed ones (Pinto et al. 2015).

However, despite the differences in size, which can be due to the above-explained factors, this study found an overall wing shape similarity among El. nigrita populations, and a lack of population differentiation using wing shape data. Even though the sampling areas are up to $1000 \mathrm{~km}$ apart, discriminant analysis for each of the nine El. nigrita geographical populations (Figure S2, Supporting information) indicated slight dissimilarities between all populations, although the scores of Mahalanobis and Procrustes distances were not correlated with geographical distance. This result is corroborated by the Mantel test, which showed no significant correlation between the morphological and geographical distances. Consequently, if there is micro-differentiation among El. nigrita populations, geographic distance seems to be an unimportant component that could explain the intra-specific morphometric variability. At the site sampling (or population) level, the morphospace of the first two canonical variables showed that there was no clear-cut separation between the groups.

Previous studies have shown that Euglossini bees have a high capacity to fly long distances (Janzen 1971; Kroodsma 1975; Ackerman et al. 1982), which is one of the major characteristics of this tribe and is a plausible explanation for the absence of population structure and the similarity of these bee populations. Raw (1969) reported El. nigrita as a high dispersal species. Euglossine males fly long distances to search for nectar, but also for the collection of floral fragrances, which can play the role in sexual selection (Janzen 1971; Kroodsma 1975; Ackerman et al. 1982; Roubik and Hanson 2004).

Our results agree with previous observations that orchid bees have a weak population structure (Grassi-Sella et al. 2018). Similar to this previous study, our sampling sites are surrounded by urban areas and large monocultures, which could be a barrier for the dispersal of the individuals. Nonetheless, we observed high similarity among all groups. As demonstrated by Dick et al. (2004), long-distance dispersal can contribute to the maintenance of gene flow, although other studies indicate that the flight range among orchid bees can vary considerably (Wikelski et al. 2010; Pokorny et al. 2015). Analysis of mitochondrial and microsatellite polymorphisms of some $E l$. nigrita populations of our study show that there is no detectable population structuring and high genetic diversity, with continuous 


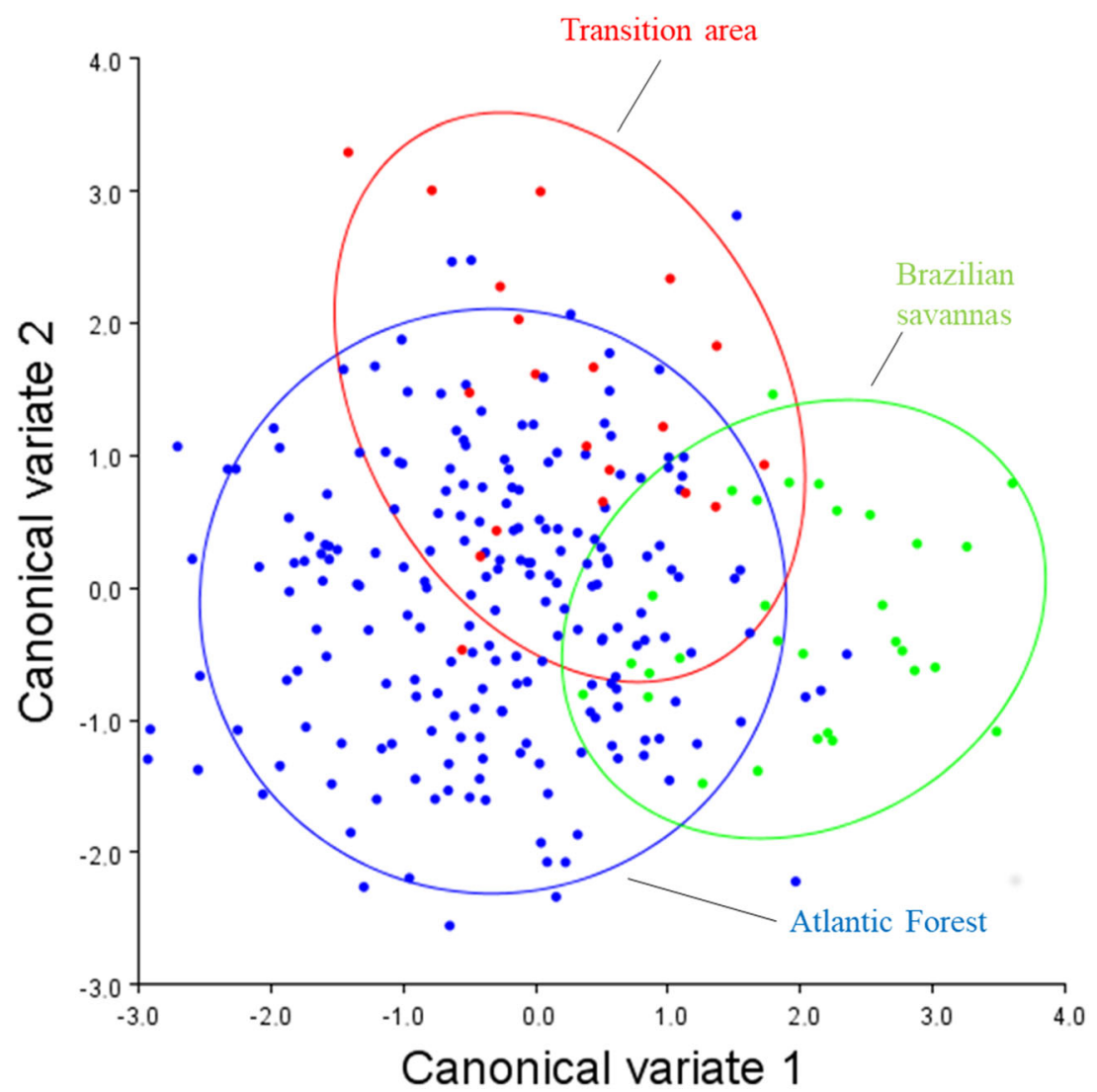

Figure 3. Two-dimensional ordination of Eulaema nigrita bees from Atlantic Forest remnants and Brazilian Savannas in the states of São Paulo (SP) and Mato Grosso do Sul (MS) based on canonical variate analysis (CVA). Transition area Atlantic Forest and Brazilian Savanna in Parque Estadual de Vassununga (PEV). Scatterplot of individual scores from the canonical variant analysis of landmarks when bees were grouped according to their biomes; the first two canonical variate functions explained $76.26 \%$ and $23.74 \%$ of the between-group variance, respectively.

gene flow occurring naturally among them (unpublished results). This corroborates other studies that have shown that euglossine bees exhibit high genetic diversity and low population structure (Souza et al. 2010; Cerântola et al. 2011; Zimmermann et al. 2011; Suni and Brosi 2012; Rocha-Filho et al. 2013). Dick et al. (2004) observed identical mitochondrial DNA haplotypes in cross-Andean populations of El. nigrita. Another study found no significant genetic differentiation between samples of El. nigrita from island and mainland, as well as Eulaema cingulata and Euglossa cordata (Rocha-Filho et al. 2013), corroborating the idea that the distance between the areas did not constitute a barrier for these species.
However, a slight eco-region pattern in wing size and shape variation was detected when populations were pooled. It is worth mentioning that our sampling sites are located within the Atlantic forest fragments, Brazilian Savanna areas, and a transition area between these biomes. Both areas are among the top 25 global biodiversity hotspots due to the high number of endemic species, many of which live under the constant threat of decline (Myers et al. 2000). When we analyzed the dendrograms of morphological similarity, built based on both the Mahalanobis and Procrustes distances (Figure S3, Supporting information), we observe the same pattern, with aggrupation following environmental characteristics. This 


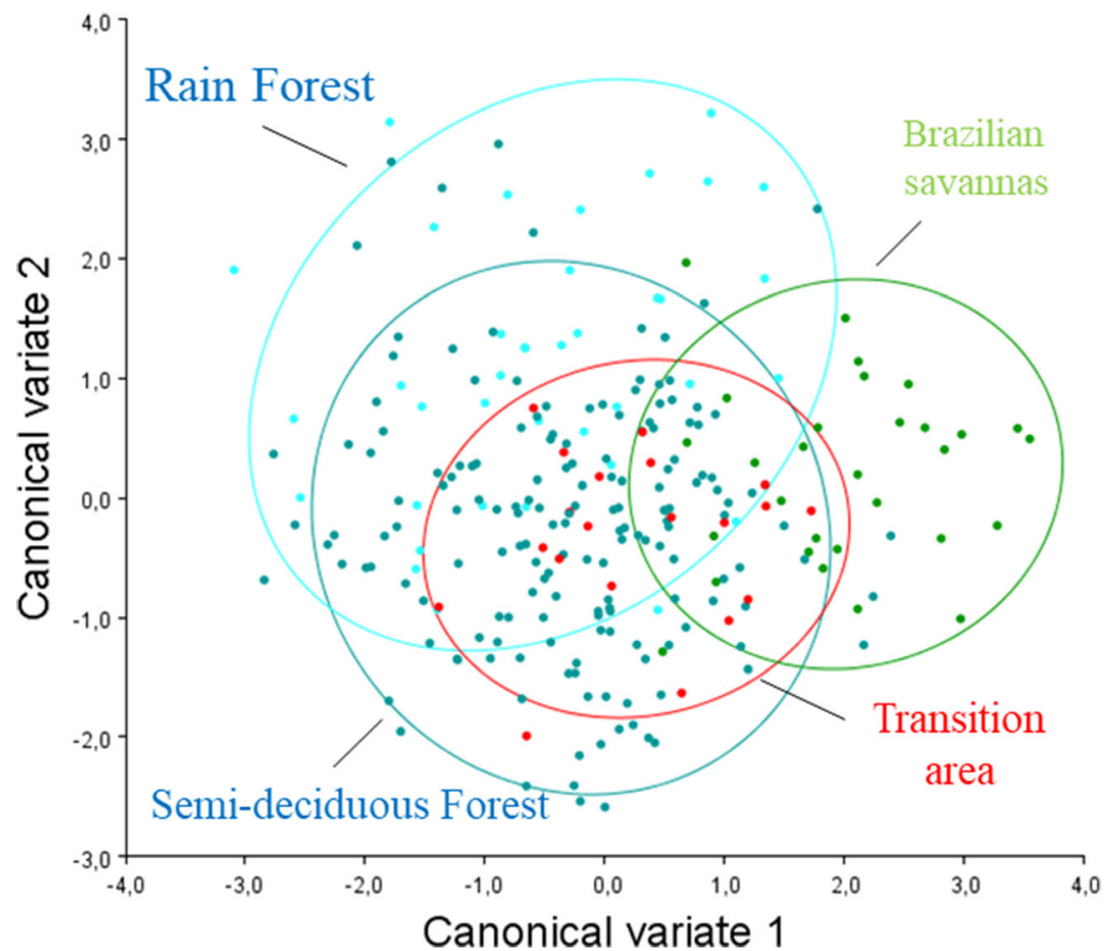

Figure 4. Two-dimensional ordination of Eulaema nigrita bees from Atlantic Forest remnants and Brazilian Savannas in the states of São Paulo (SP) and Mato Grosso do Sul (MS) based on canonical variate analysis (CVA). Transition area Atlantic Forest and Brazilian Savanna in Parque Estadual de Vassununga (PEV). Scatterplot of individual scores from the canonical variant analysis of landmarks when bees were grouped according to their physiognomies; the first two canonical variate functions explained $58.33 \%$ and $23.93 \%$ of the between-group variance, respectively.

tendency of grouping by landscape features may be due to phenotypic plasticity, a common feature found in insects (Whitman and
Agrawal 2009) or to the existence of locally adapted traits that are kept due to the philopatric behavior of Euglossini females a

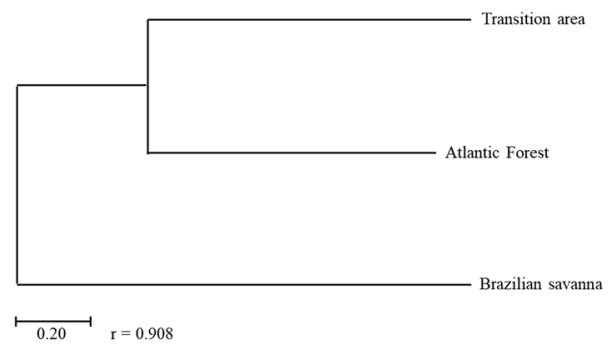

b

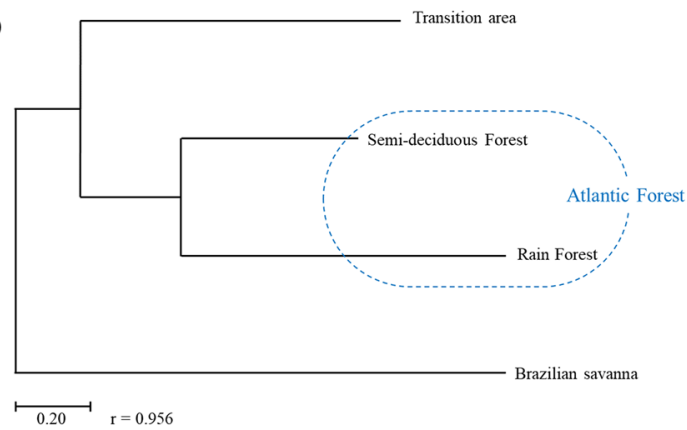

Figure 5. Neighbor-joining dendrogram of Eulaema nigrita bees constructed based on the Mahalanobis squared distances between the centroids. Transition area Atlantic Forest and Brazilian Savanna in Parque Estadual de Vassununga (PEV). a Neighbor-joining dendrogram of E. nigrita when were grouped according to their biomes. b Neighbor-joining dendrogram of $E$. nigrita when bees were grouped according to their physiognomies. 

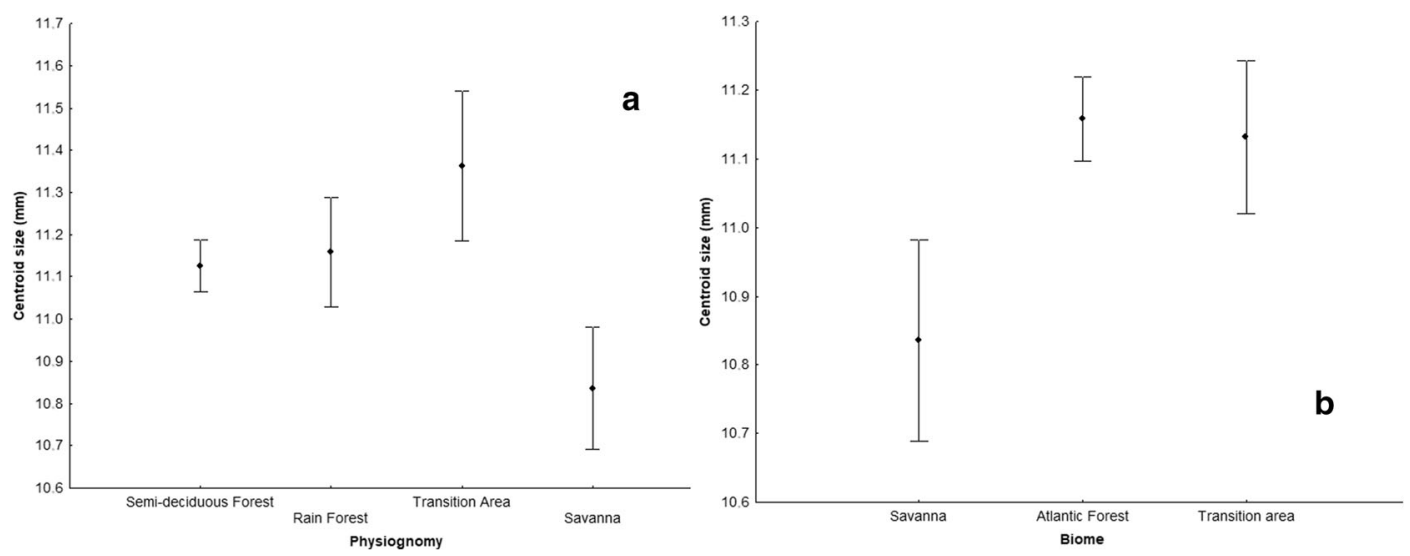

Figure 6. Mean size and standard deviation of the centroid size of Eulaema nigrita wings from different a physiognomies and $\mathbf{b}$ biomes.

(Garófalo 1992; López-Uribe et al. 2008). Similar results are observed in other orchid bee species (Grassi-Sella et al. 2018), and these results and others studies (Janzen 1971; Kroodsma 1975; Ackerman et al. 1982) support the hypothesis that males of some euglossine species are able to fly between distant locations, through biomes, likely covering distances that are greater than the closest points between two areas.

For El. nigrita, samples from the transition area overlap with samples from different areas, especially for physiognomies like Atlantic semi-deciduous forest and part of Brazilian Savanna. This result corroborates the assertion that the Euglossini fauna from Savannas is a subset of forest species (Anjos-Silva 2008; Faria and Silveira 2011; Martins et al. 2018) given that the specimens from our study and others were captured in the gallery forests of the Brazilian Savannas. According to Martins et al. (2018), the gallery forests of the Brazilian Savannas could constitute an essential route for dispersion of orchid species. Besides, high discrimination rates for biomes and physiognomies were found, but in the crossvalidation test, the rate of correct classification was somewhat lower, whose results were very similar to those found in the literature for different populations of other orchid bees species (Grassi-Sella et al. 2018), indicating high dispersion rates for some species of this tribe.
In summary, morphological distances among populations and morphological diversity of El. nigrita do not seem to be affected by geographical linear distances; however, the effect of environment on wing traits needs further evaluation to elucidate patterns of environmental gradients acting upon El. nigrita across its distribution. It is already known that El. nigrita individuals sampled in the same place in different seasons (rainy and dry) and in different years (15 years spam) do not present significant shape differences (unpublished results) but further studies are needed to clarify the effects of different environmental characteristics over these morphometric features. Finally, the results of our study expand knowledge of the euglossine population structure, information useful to guide conservation strategies for this group.

\section{ACKNOWLEDGMENTS}

The authors thank the Agência Paulista de Tecnologia dos Agronegócios (APTA-SAA, SP), in particular, Dr. Érica Weinstein Teixeira, for support and infrastructure for our sampling in Ubatuba and Pindamonhangaba. We also thank IBAMA (Brazilian Institute of Environment and Renewable Natural Resources)/ICMBio-Sisbio (Institute Chico Mendes - MMA) for permission to collect bees. Dr. S. Hollis Woodard kindly helped us improve the English of the manuscript. 


\section{AUTHORS' CONTRIBUTIONS}

CPC: data acquisition, data analysis, and wrote the paper. TMF: supervisor and wrote the paper. CCASM, RPD, WMSS, and CAG: data acquisition. All authors read and approved the final manuscript.Funding information

Financial support was provided by FAPESP (Process 2011/07857-9 to TMF and Process 2013/ 02158-0 to CPC) and by FUNDECT (Process: $59 / 300.086 / 2015$ to RPD). This study was financed in part by the Coordenação de Aperfeiçoamento de Pessoal de Nível Superior Brasil (CAPES) - Finance Code 001 to CASM.

La variabilité morphologique de l'abeille à orchidée Eulaema nigrita (Hymenoptera, Apidae, Euglossini) peut s'expliquer par la variation du biome, mais pas par la distance entre les populations.

Euglossini / morphométrie géométrique / savane brésilienne / forêt atlantique.

Morphologische Variabilität bei der Prachtbiene Eulaema nigrita (Hymenoptera, Apidae, Euglossini) kann durch Variation des Bioms erklärt werden, aber nicht durch die Distanz zwischen Populationen.

Euglossini / geometrische Morphometrie / Brasilianische Savanne / Atlantischer Wald.

\section{REFERENCES}

Ackerman J.D. (1983) Diversity and seasonality of male euglossine bees (Hymenoptera: Apidae) in central Panama. Ecology 64, 274-283.

Ackerman J.D., Mesler M.R., Lu K.L., Montalvo A.M. (1982) Food-foraging behavior of male Euglossini (Hymenoptera: Apidae): vagabonds or trapliners? Biotropica 14, 241-248.

Aguiar W.M., Gaglianone M.C. (2012) Euglossine bee communities in small forest fragments of the Atlantic Forest, Rio de Janeiro state, southeastern Brazil (Hymenoptera, Apidae). Rev. Bras. Entomol. 56, 210-219.

Aldaz J.M. (1994) Habitat destruction and the dynamics of metapopulations. J. of Anim. Ecol. 63, 492-493.
Alder G.H. (1994) Tropical forest fragmentation and isolation promote asynchrony among populations of a frugivorous rodent. J. Anim. Ecol. 63, 903-911.

Anjos-Silva E.J.D. (2008) Discovery of Euglossa (Euglossa) cognata Moure (Apidae: Euglossini) in the Platina Basin. Mato Grosso State, Brazil. Biota Neotrop. 8, 79-83.

Batalha M.A., Martins F.R. (2004) Reproductive phenology of the Cerrado plant community in Emas National Park. Aust. J. Bot. 52, 149-161.

Boff S., Soro A., Paxton R.J., Alves-dos-Santos I. (2014) Island isolation reduces genetic diversity and connectivity but does not significantly elevate diploid male production in a neotropical orchid bee. Conserv. Genet. 15, 1123-1135.

Bonatti V., Simões Z.L.P., Franco F.F., Francoy T.M. (2014) Evidence of at least two evolutionary lineages in Melipona subnitida (Apidae, Meliponini) suggested by mtDNA variability and geometric morphometrics of forewings. Naturwissenschaften 101, 17-24.

Bookstein F.L. (1998) A hundred years of morphometrics. Acta Zool. Acad. Sci. Hung. 44, 7-59.

Brown, M. J. F., Paxton, R. J. (2009) The conservation of bees: a global perspective. Apidologie 40, 410-416.

Bullock, S.H. (1999) Relationships among body size, wing size and mass in bees from a tropical dry forest in México. J. Kansas Entomol. Soc. 72, 426-39.

Cerântola N.D.C.M., Oi C.A., Cervini M., Del Lama M.A. (2011) Genetic differentiation of urban populations of Euglossa cordata from the state of São Paulo, Brazil. Apidologie 42, 214-222.

Cordeiro G.D., Boff S., Caetano T.A., Fernandes P.C., Alves-dos-Santos I. (2013). Euglossine bees (Apidae) in Atlantic Forest areas of São Paulo state Southeastern Brazil. Apidologie 44, 254-267.

Costa, C.P., Francoy, T.M. (2017). The impact of different phytophysiognomies on the composition of orchid bee communities (Hymenoptera: Apidae: Euglossini) in the Atlantic Forest in Brazil. Ann. Entomol. Soc. Am. 110, 255-262.

De Souza D.A., Wang Y., Kaftanoglu O., De Jong D., Amdam G.V., Gonçalves L.S., Francoy T.F. (2015) Morphometric identification of queens, workers and intermediates in vitro reared honey bees (Apis mellifera). PLoS ONE 10, 1-14.

Debat V., Bégin M., Legout H., David J.R. (2003) Allometric and nonallometric components of Drosophila wing shape respond differently to developmental temperature. Evolution 57, 2773-2784.

Dick C.W., Roubik D.W., Gruber K.F., Bermingham E. (2004) Long-distance gene flow and cross-Andean dispersal of lowland rainforest bees (Apidae: Euglossini) revealed by comparative mitochondrial DNA phylogeography. Mol. Ecol. 13, 3775-3785.

Dressler R.L. (1982) Biology of the orchid bees (Euglossini). Annu. Rev. Ecol. Evol. Syst. 13, 373394. 
Dujardin J.P. (2008) Morphometrics applied to medical entomology. Inf. Genet. Evol. 8, 875-890.

Faria L.R.R., Silveira F.A.D. (2011). The orchid bee fauna (Hymenoptera, Apidae) of a core area of the Cerrado, Brazil: the role of riparian forests as corridors for forest-associated bees. Biota Neotrop. 11, 87-94.

Francisco F.O., Nunes-Silva P., Francoy T.M., Wittmann D., Imperatriz-Fonseca V.L., Arias, M.C., Morgan, E. D. (2008) Morphometrical, biochemical and molecular tools for assessing biodiversity. An example in Plebeia remota (Holmberg, 1903) (Apidae, Meliponini). Insect. Soc. 55, 231-237.

Francoy T.M., Wittmann D., Drauschke M., Müller S., Steinhage V., Bezerra-Laure M.A.F, De Jong D., Gonçalves L.S. (2008) Identification of Africanized honey bees through wing morphometrics: two fast and efficient procedures. Apidologie 39, 488-494.

Francoy T.M., Silva R.A.O., Nunes-Silva P., Menezes C., Imperatriz-Fonseca V.L. (2009) Gender identification of five genera of stingless bees (Apidae, Meliponini) based on wing morphology. Genet. Mol. Res. 8, 207214.

Francoy T.M., Grassi M.L., Imperatriz-Fonseca V.L., de Jesus May-Itza W., Quezada-Euán J.J.G. (2011). Geometric morphometrics of the wing as a tool for assigning genetic lineages and geographic origin to Melipona beecheii (Hymenoptera: Meliponini). Apidologie 42, 499-507.

Francoy T.M., Franco F.F., Roubik D.W. (2012) Integrated landmark and outline-based morphometric methods efficiently distinguish species of Euglossa (Hymenoptera, Apidae, Euglossini). Apidologie 43, 609-617.

Francoy T.M.; Bonatti V., Viraktamath S., Rajankar B.R. (2016) Wing morphometrics indicates the existence of two distinct phenotypic clusters within population of Tetragonula iridipennis (Apidae: Meliponini) from India. Insectes Soc. 63, 109-115.

Freiria G.A., Ruim J.B., De Souza R.F., Sofia S.H. (2012) Population structure and genetic diversity of the orchid bee Eufriesea violacea (Hymenoptera, Apidae, Euglossini) from Atlantic Forest remnants in southern and southeastern Brazil. Apidologie 43 , 392-402.

Garófalo C.A. (1992) Comportamento de nidificação e estrutura de ninhos de Euglossa cordata (Hymenoptera: Apidae: Euglossini). Rev. Bras. Biol. 52, 187198.

Giangarelli D.C., Aguiar W.M., Sofia, S.H. (2015). Orchid bee (Hymenoptera: Apidae: Euglossini) assemblages from three different threatened phytophysiognomies of the subtropical Brazilian Atlantic Forest. Apidologie 46, 71-83.

Gibert P., Capy P., Imasheva A., Moreteau B., Morin J.P., Pétavy G., David J.R. (2004) Comparative analysis of morphological traits among Drosophila melanogaster and $D$. simulans: genetic variability, clines and phenotypic plasticity. Genetica 120, 165-179.

Grassi-Sella M.L., Garófalo C.A., Francoy T.M. (2018) Morphological similarity of widely separated populations of two Euglossini (Hymenoptera; Apidae) species based on geometric morphometrics of wings. Apidologie 49, 151-161.

Hurtado-Burillo M., Laura J., May-Itzá W.J., QuezadaEuán J.J., Ruiz C., De la Rúa P. (2016) A geometric morphometric and microsatellite analyses of Scaptotrigona mexicana and S. pectoralis (Apidae: Meliponini) sheds light on the biodiversity of Mesoamerican stingless bees. J. Insect Conserv. 20, 753763.

Janzen D.H. (1971) Euglossine bees as long-distance pollinators of tropical plants. Science 171, 203-205.

Jirakanjanakit N., Leemingsawat S., Dujardin J.P. (2008). The geometry of the wing of Aedes (Stegomyia) aegypti in isofemale lines through successive generations. Inf. Genet. Evol. 8, 414-421.

Klein A.M., Vaissiere B.E., Cane J.H., Steffan-Dewenter I., Cunningham S.A., Kremen C., Tscharntke T. (2007) Importance of pollinators in changing landscapes for world crops. Proc. R. Soc. B 274: 303-313.

Klingenberg C.P. (2011) MorphoJ: an integrated software package for geometric morphometrics. Mol. Ecol. Resour. 11, 353-357.

Kroodsma D.E. (1975) Flight distances of male euglossine bees in orchid pollination. Biotropica 7, 71-72.

Kumar S., Stecher G., Tamura K. (2016). MEGA7: molecular evolutionary genetics analysis version 7.0 for bigger datasets. Mol. Biol. Evol. 33, 1870-1874.

Leite G.L.D., Veloso R.V.S., Zanúncio J.C., Fernandes L.A., Almeida C.I.M. (2006) Phenology of Caryocar brasiliense in the Brazilian cerrado regions. For. Ecol. Manag. 236, 286-294.

López-Uribe M.M., Oi C.A., Del Lama M.A. (2008). Nectar-foraging behavior of Euglossine bees (Hymenoptera: Apidae) in urban areas. Apidologie 39, 410418.

Machado C.A.S., Costa C.P., Francoy T.M. (2018). Different physiognomies and the structure of Euglossini bee (Hymenoptera: Apidae) communities. Sociobiology 65, 471-481.

Martins, D.C., Albuquerque P.M.C., Silva F.S., Rebêlo J.M.M. (2018) Orchid bees (Apidae: Euglossini) in Cerrado remnants in northeast Brazil. J. Nat. Hist. 52, 627-644.

McCoy E.D., Mushinsky H.R. (1994). Effects of fragmentation on the richness of vertebrates in the Florida scrub habitat. Ecology 75, 446-457.

Mitteroecker P., Gunz P. (2009) Advances in geometric morphometrics. Evol. Biol. 36, 235-247.

Morales-Vargas E.R., Ya-Umphan P., Phumala-Morales N., Komalamisra N., Dujardin J.P. (2010) Climate associated size and shape changes in Aedes aegypti (Diptera: Culicidae) populations from Thailand. Infect. Genet. Evol. 10 , 580-585.

Morato E.F., Campos L.A.O., Moure J.S. (1992). Abelhas Euglossini (Hymenoptera, Apidae) coletadas na Amazônia Central. Revista Brasileira de Entomologia, 36, 767-771. 
Moure J.S. (1950) Contribuição para o conhecimento do gênero Eulaema Lepeletier (Hymenoptera, Apoidea). Dusenia 1, 181-231.

Myers N., Mittermeier R.A., Mittermeier C.G., Fonseca G.A., Kent J. (2000) Biodiversity hotspots for conservation priorities. Nature 403, 853-858.

Neff J.L., Simpson B.B. (1993). Bees, pollination systems and plant diversity. In: Hymenoptera and biodiversity, LaSalle J., Gauld I.D. (Eds). Wallingford, UK: CAB Int. pp. 143-67.

Nemésio A. (2009). Orchid bees (Hymenoptera: Apidae) of the Brazilian Atlantic forest. Zootaxa 2041, 1-242.

Nemésio A., Silveira F.A. (2007) Orchid bee fauna (Hymenoptera: Apidae: Euglossina) of Atlantic Forest fragments inside an urban area in Southeastern Brazil. Neotropical Entomology 36,186-191.

Oleksa A., Tofilski A. (2014) Wing geometric morphometrics and microsatellite analysis provide similar discrimination of honey bee subspecies. Apidologie 46, 4960.

Ospina-Torres R., Maria Montoya-Pfeiffer P., Parra H.A., Solarte V., Tupac Otero J. (2015). Interaction networks and the use of floral resources by male orchid bees (Hymenoptera: Apidae: Euglossini) in a primary rain forests of the Choco Region (Colombia). Rev. Biol. Trop. 63, 647-658.

Outomuro D., Johansson F. (2011). The effects of latitude, body size, and sexual selection on wing shape in a damselfly. Biol. J. Linn. Soc. 102, 263-274

Penha R.E.S., Gaglianone M.C., Almeida F.S., Boff S.V., Sofia S.H. (2015) Mitochondrial DNA of Euglossa iopoecila (Apidae, Euglossini) reveals two distinct lineages for this orchid bee species endemic to the Atlantic Forest. Apidologie 46, 346-358.

Peruquetti R.C. (2003). Variação do tamanho corporal de machos de Eulaema nigrita Lepeletier (Hymenoptera, Apidae, Euglossini). Resposta materna à flutuação de recursos? Rev. Bras. Zool. 2 , 207-212.

Peruquetti R.C., Antonio L., Campos D.O., Diniz C., Coelho P. (1999). Abelhas Euglossini (Apidae) de áreas de Mata Atlântica: abundância, riqueza e aspectos biológicos. Rev. Bras. Zoool. 16, 101-118.

Pinto, N.S., Silva, D.P., Rodrigues, J.G., De Marco Jr, P. (2015). The size but not the symmetry of the wings of Eulaema nigrita Lepeletier (Apidae: Euglossini) is affected by human-disturbed landscapes in the Brazilian Cerrado Savanna. Neotrop. Entomol. 44, 439-447.

Pokorny T., Loose D., Dyker G., Quezada-Euán J.J.G., Eltz T. (2015) Dispersal ability of male orchid bees and direct evidence for long-range flights. Apidologie 46, 224-237.

Polak M., D.E. Kroeger, I.L. Cartwright, C. (2004) Ponce de Leon genotype-specific responses of fluctuating asymmetry and of pre-adult survival to the effects of lead and temperature stress in Drosophila melanogaster. Environ. Pollut. 127, 145-155.

Quezada-Euán, J.J.G., López-Velasco, A., Pérez-Balam, J., Moo-Vale H., Velazquez-Madrazo A., Paxton R.J. (2011) Body size differs in workers produced across time and is associated with variation in the quantity and composition of larval food in Nannotrigona perilampoides (Hymenoptera, Meliponini). Insect. Soc. 58, 31-38.

Quezada-Euán J.J.G., Sheets H.D., De Luna E. and Eltz T. (2015) Identification of cryptic species and morphotypes in male Euglossa: morphometric analysis of forewings (Hymenoptera: Euglossini). Apidologie 46, 787-795.

R Development Core Team. (2017). R: A language and environment for statistical computing. Vienna, Austria: The R Foundation for Statistical Computing. ISBN: 3-900051-07-0. Available online at http://www.R-project.org/.

Ramalho A.V., Gaglianone M.C., Oliveira, M.L. (2009). Comunidades de abelhas Euglossina (Hymenoptera, Apidae) em fragmentos de Mata Atlântica no Sudeste do Brasil. Rev. Bras. Entomol. 53, 95-101.

Ramírez S. (2019). Pollinator specificity and seasonal patterns in the euglossine bee-orchid mutualism at La Gamba Biological Station. Acta ZooBot Austria 156, 171-181.

Ramirez Arriaga E., Martinez Hernandez E. (1998). Resources foraged by Euglossa atroveneta (Apidae: Euglossinae) at Unión Juárez, Chiapas, Mexico. A palynological study of larval feeding, Apidologie 29, 347-359.

Ramírez S., Dressler R.L., Ospina M. (2002). Abejas euglosinas (Hymenoptera: Apidae) de la Región Neotropical: Listado de especies con notas sobre su biología. Biota Colombiana 3, 7-118.

Rattanawannee, A., Jeratthitikul, E., Duangpakdee, O., Oldroyd, B. P. (2017). Mitochondrial sequencing and geometric morphometrics suggest two clades in the Tetragonilla collina (Apidae: Meliponini) population of Thailand. Apidologie 48, 719-731

Raw A. (1989). The dispersal of euglossine bees between isolated patches of eastern Brazilian wet forest (Hymenoptera, Apidae, Euglossini). Rev. Bras. Entomol. 33, 103-107.

Rebêlo J.M.M., Garófalo C.A. (1991). Diversidade e sazonalidade de machos de Euglossini (Hymenoptera, Apidae) e preferência por iscas-odores em um fragmento de floresta no sudeste do Brasil. Rev. Bras. Biol. 51, 787-799.

Rebêlo J.M.M., Garófalo C.A. (1997). Comunidades de machos de Euglossini (Hymenoptera: Apidae) em matas semidecíduas do nordeste do Estado de São Paulo. An. Soc. Entomol. Bras. 26, 243-255.

Rebêlo J.M.M, Rêgo M.M., Albuquerque P.M.C., Melo G.A.R., Alves-dos-Santos I. (2003) Abelhas (Hymenoptera, Apoidea) da região setentrional do Estado do Maranhão, Brasil. In: Melo G.A.R., Alves-dos-Santos I. (Eds). Apoidea Neotropica: Homenagem aos 90 anos de Jesus Santiago Moure. Criciúma, UNESC. pp. 265-278.

Rocha-Filho L.C., Garófalo C.A. (2013) Community ecology of euglossine bees in the coastal Atlantic Forest of São Paulo State, Brazil. J. Insect Sci. 13, 1-19. 
Rocha-Filho L.C., Garófalo C.A. (2014). Phenological patterns and preferences for aromatic compounds by male Euglossine Bees (Hymenoptera, Apidae) in two coastal ecosystems of the Brazilian Atlantic Forest. Neotrop. Entomol. 43, 9-20.

Rocha-Filho L.C., Cerântola N.C.M., Garófalo C.A., Imperatriz-Fonseca V.L., Del Lama M.A. (2013) Genetic differentiation of the Euglossini (Hymenoptera, Apidae) populations on a mainland coastal plain and an island in southeastern Brasil. Genetica 141, 65-74.

Rohlf F.J. (2015). The tps series of software. Hystrix 26, 14.

Roubik D.W., Hanson P.E. (2004) Orchids bees: biology and field guide. INBIO, San Jose

Silva C.I., Bordon N.G., Rocha Filho L.C., Garófalo C.A. (2012). The importance of plant diversity in maintaining the pollinator bee, Eulaema nigrita (Hymenoptera: Apidae) in sweet passion fruit fields. Rev. Biol. Trop. $60,1553-1565$.

Silva F.L., Sella M.L.G., Francoy T.M., Costa A.H.R. (2015). Evaluating classification and feature selection techniques for honeybee subspecies identification using wing images. Comput. Electron. Agric. 114, 68-77.

Silveira G.C., Freitas R.F., Tosta T.H.A., Rabelo L.S., Gaglianone M.C., Augusto S.C. (2015) The orchid bee fauna in the Brazilian savanna: do forest formations contribute to higher species diversity? Apidologie 46, 197-208.

Sofia S.H., Santos A.L., Silva, C.R.M. (2004). Euglossine bees (Hymenoptera, Apidae) in a remnant of Atlantic Forest in Paraná State, Brazil. Iheringia, Sér. Zool. 94, 217-222.

Souza R.O., Del Lama M.A., Cervini M., Mortari N., Eltz T., Zimmermann Y., Bach C., Brosi B.J., Suni S.,
Quezada-Euán J.J.G., Paxton R.J. (2010) Conservation genetics of neotropical pollinators revisited: microsatellite analysis suggests that diploid males are rare in orchid bees. Evolution 64, 3318-3326.

Suni S.S., Brosi B.J. (2012) Population genetics of orchid bees in a fragmented tropical landscape. Conserv. Genet. 13, 323-332.

Tonhasca A., Albuquerque G.S., Blackmer J.L. (2003) Dispersal of Euglossine bees between fragments of the Brazilian Atlantic Forest. J. Trop. Ecol. 19, 99-102.

Whitman D.W., Agrawal A.A. (2009) What is phenotypic plasticity and why is it important? In: Phenotypic plasticity of insects, Whitman D.W., Ananthakrishnan T.N. (Eds.). pp. 1-63

Wikelski M., Moxley J., Eaton-Mordas A., López-Uribe M.M., Holland R., Moskowitz D., Roubik, D.W., Kays, R. (2010) Large-range movements of neotropical orchid bees observed via radio telemetry. PLoS ONE 5, e10738.

Willmer P. (2011) Pollination and floral ecology. Princeton University Press, Princeton.

Zelditch M.L., D.L. Swiderski, H.D. Sheets, W.L. Fink (2004) Geometric morphometrics for biologists: a primer. Elsevier Academic Presss, San Diego.

Zimmermann Y., Schorkopf D.L.P., Moritz R.F.A., Pemberton R.W., Quezada-Euan J.J.G., Eltz T. (2011) Population genetic structure of orchid bees (Euglossini) in anthropogenically altered landscapes. Conserv. Genet. 12, 1183-1194.

Publisher's note Springer Nature remains neutral with regard to jurisdictional claims in published maps and institutional affiliations. 